\title{
Cyberculture and Occupational Therapy: Creating Connections
}

\section{Sabrina Helena Ferigato, PhD}

Occupational Therapy Department, Federal University of São Carlos, Brazil. B.OT (Pontifical Catholic University of Campinas PUCCAMP); MPhil (PUCCAMP); PhD in Collective Health (University of Campinas (UNICAMP).

\section{Carla Regina Silva, PhD}

Occupational Therapy Department, Federal University of São Carlos, Brazil. B.OT - Federal University of São Carlos (UFSCar); M.Ed.(Federal University of São Carlos - UFSCar); PhD in Education (UFSCar).

\section{Gerusa Ferreira Lourenço, PhD}

Occupational Therapy Department, Federal University of São Carlos, Brazil; BOT (Federal University of São Carlos - UFSCar), M.OT and PhD in Special Education (Federal University of São Carlos - UFSCar).

This paper explores the contemporary challenges and possibilities that cyberculture adds to occupational therapy. This analysis is necessary because we are experiencing a gradual and irreversible virtualisation of our everyday life and actions along with the expansion of cyberspace. The theoretical techniques of occupational therapy and the theories of Pierre Levy suggest that these challenges are at a minimum on two levels: (I) the need to update our object of intervention: human participation and occupation in the context of cyberculture, and (2) the identification and creation of current demands and new methods of intervention, respectively, in this field that originate from the ethical, aesthetic, political, and social shaping of human relations.

Key words: Occupational therapy, cyberculture, social participation, communication, human occupation

\section{INTRODUCTION}

This paper explores the perspectives and challenges of occupational therapy in the context of cyberculture, which includes the establishment of a communicational and relational ecology due to the advent of cyberspace and the proliferation of new information and communication technologies.

Considering that virtual networks and connectivity significantly change the way people relate to each other and lead their everyday lives, we investigate the relevance of these changes to the occupational life of individuals and groups, focusing on the impact of cyber space on the occupational therapy profession.

This opinion piece does not deal with the paradigmatic changes caused by cyberculture but analyses how cyberculture can transform everyday lives and occupational therapy practices. These transformations occur not only because of the multiplier effect of the media, but as a direct result of the virtualisation of cultural and social relations. In this way, the virtualisation changes the scope of individual and collective participation.

We therefore contend that this reflection is relevant to any field of knowledge which has human occupation as the study. To establish the relationship between the core of occupational therapy and this contemporary phenomenon, we refer to the conceptual approach of Pierre Levy ${ }^{1,2}$ in relation to occupational therapy frameworks.

We begin with a brief explanation of the concepts of cyberculture and cyber-space and then present the analysis involving occupational therapy at two levels: (I) cyberculture and the major transformations produced in everyday life as well as in the construction of new socio-cultural realities, and (2) perspectives and challenges of occupational therapy in the age of cyberculture.

\section{ARGUMENT AND CRITICAL DISCUSSION}

\section{Cyberculture and cyberspace}

The etymology of the word cyberculture comes from the combination of the words cybernetics and culture. Norbert Wiener ${ }^{3}$ created the definition of cybernetics, as a science that studies the control and communication between animal and machine. The theory of communication and of control, as well as the term 'feedback' are the elements of a transdisciplinary body of knowledge labelled 'cybernetics'.

Castro, Dahlin-Ivanoff, and Mårtensson ${ }^{4}$ summarise the relevance of culture to occupational therapy through a literature review and highlight that the lack of critical insight into professional knowledge increases the risk that occupational therapy will remain content with the current understanding of culture, based on our existing knowledge base.

We have highlighted two of the aforementioned terms: 'culture' and 'everyday life', which are considerably significant for occupational therapy and are used by occupational therapists to refer to those contexts within which all occupations and activities take place 5 .

Therefore, 'everyday life' would be a singular construct of each subject, made up from different activities in different performance areas. "Culture then, would be the universe in which all human activity is created and develops; the collective space where activities gain significance"6:72. Occupational therapy practices are constantly involved in a cultural process of doing, knowledge and technology.

When we directly relate the aspects of culture and everyday life to cyber activities, we notice one of the main phenomena related to cyberculture: the emergence of cyberspace. 
According to Lévy', cyberspace represents a virtualisation of reality and establishes a new relationship within the space-time domain, using a wide range of possibilities of virtual interactions that often arise from the same structures in the "non-virtual" world but without complete correspondence with it, since the virtual world engenders its own codes and structures.

Lévy points out that virtuality is not necessarily the opposite of reality. Therefore, the 'virtual' results in the 'real'. According to him, "virtual is that which exists only in potency and not in act"2:47. To connect the philosophical understanding of 'virtual' to the contemporary context, Lévy affirms that it in the virtual world, every entity is 'de-territorialised', and is able to generate a number of concrete manifestations at different times and certain places, without however, being itself attached to a particular place or time ${ }^{6: 47}$.

These virtual spaces involve speaking and writing as well as virtualization of various modes of communication and human interaction, which profoundly alter our thought processes, helping us make sense of the world, relate to each other and generate knowledge. In this scenario, the cognitive, linguistic, and affective aspects become more influential than ever, producing new possibilities of subjectivity and socialisation ${ }^{7}$.

Cyberspace, as a new place of socialisation, creates new forms of social relations, with their own codes and specificities, as well as new processes of subjectivity ${ }^{8}$. To some extent, those new codes are completely original and sometimes appear as a reformulation of the already known possibilities of socialisation.

\section{CHANGES PRODUCED IN THE SPHERE OF EVERYDAY LIFE AND IN THE CONSTRUCTION OF SOCIOCULTURAL PARADIGMS}

The changes caused by cyberculture are noticeably present in our everyday life. Santaella' states that the new information and communication technologies are constantly changing entertainment and leisure formats, as well as all other spheres of society: work, political management, military and police activities, consumerism, communication, education and as such, culture as a whole.

Occupational therapists commonly share the idea that "it is the study of social practices, going through everyday life that enables our understanding of social reality and opens the doors to its transformation" $"$ : 105 .

According to Guajardo, Kronenberg and Ramugondo 10:8 "all practice is a social act. No practice is individual, not even when it is carried out by a single person. All human occupation makes reference to a context, to a personal sense, to a process of cultural appropriation".

The cyberspace has brought changes to all our social and everyday life practices, such as the reconfiguration of one's private life and it directs the manner in which we communicate and express ourselves (social networks, e-mail, fast communication programmes).

It is now possible to increase space and time, for occupations can now be virtualised without the limits of spatial and temporal boundaries; to create new ways to utilise playful devices and interactive games; reconfigure practical life activities; expand the use of free time on surfing the Internet; as well as creating cyber cities, new opportunities for leisure, new forms of artistic expression, cognitive and pedagogical approaches, and new forms of collective political demands and social struggles. We found that these changes demonstrate a new ground for subjectivity and drastically influence the occupational life of individuals and groups.

Lévy ${ }^{7}$ finds a set of significant socio-political and cultural transformations including the amplification of virtual interactivity forms; communication through shared social networks; new ways of organizing social activism and social movements via cyber-activism and activation of networks; online interconnection of cultural, artistic, and economic processes; the adequacy of the aesthetic aspects of cyberculture and its techno-social devices; the advent of new media and information relations; the initiation of new teaching-learning mechanisms and profound changes in the production of knowledge in sharing that knowledge.

Currently, "humanity reconnects itself"7:195, and with new technologies, these connections are intensified on a scale never seen before. This global virtual presence provides an opportune environment for the dissemination of knowledge and skills for cooperation and collective construction of knowledge which Lévy' labeled as collective intelligence.

In other words, although we are inclined to believe that intelligence is the property of individuals, we need to consider the premise that intelligence is always the product of a collective psyche which constitutes ideas, thoughts, cognitive modules, neurons, cells, organisms, people, and species.

According to Teixeira ${ }^{7}$, from a cognitive perspective, collective intelligence transforms into an autonomous learning ability, and from a historical perspective, it transforms through natural evolution, which - in the words of Lévy ${ }^{2}$ - comprises an art of self-creation that strengthens the construction of collectiveness.

\section{PERSPECTIVES AND CHALLENGES OF OCCUPATIONAL THERAPY IN THE AGE OF CYBERCULTURE}

Considering the phenomenon of cyberculture as a given on a global scale, we attempted to analyse its irreversibility and its consequences for the individual and collective spheres ${ }^{5}$, in view of considering the transformations that such changes bring to occupational therapy.

I. Firstly, as explained in the previous sections, it is necessary to recognise a significant change in our object of intervention: human occupation and participation.

2. Secondly, it is necessary to explore the new demands created by the new ethical, aesthetic, political, and social shaping of human activity.

With regard to the traditional areas of expertise in occupational therapy, we suggest that there is at least one common issue shared by all population groups targeted by the profession, which is the 'exclusion process', where certain groups with different characteristics are 'excluded'.

Professionals working in various branches of occupational therapy - physical disorders, mental health, primary care, hospital care, social, culture and education - are commonly called on to intervene in a broad way in the occupational life of individuals, groups or communities that are going through exclusion situations or processes ${ }^{\prime \prime}$.

According to Foucault ${ }^{12}$, the exclusion of any 'differences' in the Western world involves one of the most important and farreaching decisions of humanity, and could establish itself as a power technology that structures an entire society. Therefore, more than marginalising and segregating, the exclusion processes shape modes of social organisation, produce normative standards, affirm values and relations of knowledge-power, and define the creation of a universal sense established by a dominant majority.

According to Lévy', social exclusion is the main contemporary form of oppression, social injustice, and misery. He observes that the age of cyberculture encourages a radical renewal of society and generates new forms of inclusion and exclusion, related to the inequality among different social classes or even between rich and poor countries.

Access to cyberspace requires the availability of communication infrastructures, high-cost machines, network access, and digital devices and requires a prior learning process for the use of new technological devices.

Apart from the technological obstacles, Lévy' illustrates the following human obstacles: institutional, political, and cultural factors obstructing the access to communal and interactive forms of 
communication, in addition to pervasive feelings of incompetence and disqualification with regard to the use of New Information and Communication Technologies (NICT)*.

However, when each new communication system excludes those individuals, it is not about an adherence to a universal sense that previously manifested in the form of regulations, but it is about a connection system. In the context of cyberculture, the excluded individuals are the disconnected ones'. This does not mean denial, removal, or other forms of segregation, but the improvement of another way of causing marginalization and social exclusion.

In this regard, this new dimension of exclusion poses an additional problem to professionals involved in social inclusion initiatives, including occupational therapists.

It is important to remember that the obstacles highlighted may exacerbate the barriers already faced by occupational therapists, such as, physical, functional, cognitive, sensorial, mental, and communicational limitations; or situations causing social vulnerability. If facing and overcoming these barriers already form part of the occupational therapists' scope of work, we have to focus on the incorporation of new forms of exclusion in contemporary situations. Furthermore, it is important to identify how the virtualisation of occupations and the emergence of new technologies may serve as the devices to foster emancipation and inclusion.

3. In the third and final stage, we would like to explore new possibilities of intervention in occupational therapy in the age of cyberculture, and above all, the new features and devices at our disposal for an intervention in relation to our needs and current possibilities.

In this stage, some possibilities of intervention are already clearly explored and incorporated by many occupational therapists in their group and individual actions. We may cite as an example the development of assistive technology to allow vulnerable populations (especially people with physical or sensorial disability, or both) to use new information and communication technologies as well as to enable targeted actions, nonverbal communication, and educational and social inclusion ${ }^{13}$.

Another strategy already addressed by occupational therapists and professionals in other disciplines include digital inclusion actions and the use of virtual reality, which also promote individual, group, and community interventions ${ }^{14}$.

Silva, Cardinalli, and Lopes ${ }^{15}$ present an analysis of a implementing a blog and the use of interactive pictorial resources for the improvement of vulnerable young clients by expanding their possibilities of communication and social participation. They claim that the strategies were quite effective for occupational therapy in the social field, as they strengthened the voice of those who did not possess a listening platform and fostered expression and communication skills by talking to each other about the heroes of their own stories.

These examples illustrate a significant reduction of exclusion through:

(a) access to technological dimensions;

(b) "human-machine interaction", and

(c) economic conditions to access communication technologies.

Nonetheless, for such strategies, "the problem of access for all cannot be reduced to technological and financial dimensions [...] we must be able to actively participate in the information and communication processes"2:238.

From this perspective, occupational therapists, in partnership with professionals from other fields, can be strategic agents for

* According to the International Telecommunication Union (UN), as of May 26, 20I5, globally, 3.2 billion people and $46 \%$ of the homes were connected to the Internet. In 2000 , this figure had reached only 400 million. However, despite the progress, there are still 4 billion people deprived of the Internet facilities. the promotion of the clients' autonomy through the utilisation of these new forms of interaction, and for preventing new relations of dependence which might ensue from the consumption of information and communication services created for merely economic purposes.

According to Lévy ${ }^{2}$, the instruments produced in cyberculture (including National Institute of Communication Technology (NICT) social networks) should serve primarily to enrich the culture, skills, and local resources to help people collectively create networks for mutual help and strengthen collective intelligence. Further, such instruments should help people enhance their learning in groups and work collaboratively to expand access to the knowledge produced daily and to foster relationships independent of geographical boundaries. Such measures will foster autonomy, which is a significant goal of occupational therapy.

Thus, cyberspace can increase the autonomy of the subjects and the "power of collective action," especially if we assume that this "power" fundamentally depends on the ability of individuals and groups to interact, express themselves, and produce and exchange ideas ${ }^{7}$.

Based on this idea, the authors are of the opinion that cyberculture challenges us to update our occupational therapy technologies, especially with regards to (a) the instruments of intervention available in cyberspace and (b) the various participation and human action possibilities that cyberculture offers.

One of the main legacies of capitalism and positivism was the fragmentation of societal and human activity, and differences between men and women in terms of their daily activities, especially with regard to professional and learning activities ${ }^{16}$. Therefore, the age of cyberculture propels us forward to new modes of activities, showing us that - as suggested by Levy' - society is conditioned, not determined by technology.

We propose therefore, that the internet, social media and social network services virtualise and modify the everyday life of people, and thereby, we may enhance our profession if we are cognisant of the effect that culture imposes on our clients' occupational life.

Cyberculture, as much as any other type of culture, is a human creation. There is no division between the forms of culture and human action, since together they shape our sensibility and thoughts, especially when it refers to computer and digital technologies, which are technologies of intelligence?.

\section{CONCLUSION}

This opinion piece presented a relationship between cyberculture and occupational therapy on three levels: I) the analysis of individual and the social impact of virtualising everyday life; 2) the implication for the profession of new forms of exclusion that accompany cyberculture; and 3) the incorporation of new inclusion devices that emerge in cyberspace, in social networks and along with the new technological tools that are made available by the NICT.

We attempted to demonstrate that the modern-day profound cultural modulation also restructures our intervention processes as it gives new facets to the intrinsic aspects of our actions, including the virtualization of everyday life of individuals and groups and the reconfiguration of exclusion or inclusion processes.

Occupational life and the way people interact with each other, with the environment and with their occupations and activities in a contemporary world, favors the consolidation of a connected culture that is cyberculture. The concept of culture is, therefore, central to our field. Furthermore, the genesis of a 'new' occupational therapy lies in that 'new' culture.

A major characteristic of this phenomenon is the expansion of the occupational spectrum of subjects through the transition from an institutionalised culture to social and technological networks that transform the relation between knowledge, social participation, communication, work, leisure, and as a result, the production of subjectivity. It is necessary that occupational therapy transforms in consonance with those socio-cultural changes. 
Finally, occupational therapy practices should not be in dialogue only with this accelerated state of connectivity inherent to cyberculture, which constantly opens up new modes of existence; we must be attentive to the senses that 'life in connectivity and network' produce in the spheres of human occupation, in the individual and the collective, primordial sphere of our practices.

\section{REFERENCES}

I. Lévy P. Cyberculture. (Trad. Carlos Irineu da Costa). São Paulo: Editora. 34; 2010.

2. Lévy P. The Collective Intelligence: For a cyberspace anthropology. São Paulo: Loyola; 1998.

3. Wiener N. Cybernetics: Or Control and Communication in the Animal and the Machine. 2nd revised ed. Paris: Hermann and Cie \& Camb. Mass. 196I. https://en.wikipedia.org/wiki/Cybernetics:_Or_ Control_and_Communication_in_the_Animal_and_the_Machine.

4. Castro $\bar{D} E$, Dahlin-Ivanoff S, Mårtensson L. Occupational therapy and culture: a literature review. Scand J Occup Ther. Nov 2014; $2 \mathrm{I}(6): 40 \mathrm{I}-\mathrm{I4}$. http://www.tandfonline.com/doi/full// $0.3109 / \mathrm{I} 103$ 8128.2014 .898086$.

5. Galheigo SM. The everyday in Occupational Therapy: culture, subjectivity and historical social context. Rev. Ter. Ocup. Univ. São Paulo. 2003; 14(3): 104-9. http://revistas.usp.br/rto/article/ view/13924/15742.

6. Lima EMFA, Pastore, MN; Okuma, DG. Activities in the OT Field: mapping the scientific production of Brazilian occupational therapists between 1990 and 2008. Rev. Ter. Ocup. Univ. São Paulo. 20II; 22(I): 68-75. http://www.revistas.usp.br/rto/article/ viewFile/I4I 22/I5940.

7. Teixeira RR. The performance of a primary care service from the perspective of collective intelligence. Interface - Comunic, Saúde, Educ. 2005; 9(I7): 219-34. http://www.scielosp.org/pdf/icse/v9n I 7/ v9nI7a02.pdf.

8. Deleuze G, Guattari F. Mil platôs: Capitalismo e Esquizofrenia. Rio de Janeiro: Ed.34; 1995.

9. Santaella L. From media to cyberculture: the post-human advent. Revista Famecos. 2003; I (22): 23-32.

I0. Guajardo A, Kronenberg F, Ramugondo EL. Southern occupational therapies: emerging identities, epistemologies and practices. South African Journal of Occupational Therapy. 20I5; 45(I): 3-10. https:// dx.doi.org/10.17/59/2310-3833/2015/v45nola2.

II. Cronenberg F, Algado SS, Pollard N. Occupational Therapy Without Borders: Learning from the Spirit of Survivors, Volume I. Elsevier/ Churchill Livingstone; 2005.

12. Foucault, M. A história da loucura na idade clássica. Trad. José T. Coelho Neto. São Paulo: Perspectiva; 2002.

13. Wennberg, B, Kjellberg A. Participation When Using Cognitive Assistive Devices - from the Perspective of People with Intellectual Disabilities. Occup. Ther. Int. 2010; 17: 168-176. https://www.ncbi. nlm.nih.gov/pubmed/20652867.

14. Raymundo TM, Santana CS. Elderly perception about the new technologies. Inteligência Artificial. 20 I5( I8): I 2-25. http://journal. iberamia.org/index.php/intartif/article/view/60.

15. Silva CR, Cardinalli I, Lopes RE. The use of blogs and media resources in the extension of social participation and ways of communication. Cad. Ter. Ocup. UFSCar. 20I5; 23(I): I3I-I42. http://www. cadernosdeterapiaocupacional.ufscar.br/index.php/cadernos/article/ view/960.

16. Soares LBT. Occupational Therapy: logic of capital or logic of work? São Paulo: Hucitec; 1991. 